\title{
SWISS CHEESE FOR LAZY SPEAKERS: VERB OMISSIONS IN RUSSIAN AND CZECH
}

\author{
JEKATERINA MAŽARA \\ University of Zürich
}

\section{ABS TRACT}

In this paper, I will examine a specialty of colloquial Russian - the omission of verbs - and compare it to the possibilities of verb omission in Czech, where this phenomenon is rather rare. The omissions in question are to be separated from compulsory ellipses, which will not be taken into account in this paper. They are also not to be regarded as zero lexemes, which are elusive to attempts of reconstruction. The nature of this third kind of omission itself presents a frame for the comparison, since these omissions can be placed along two scales, that of AMBIGUOUS/VAGUE Vs. UNEQUIVOCALLY RECOVERABLE and FREE FORMATION VS. PHRASEOLOGICALLY BOUND PHRASE. The comparison of verb omissions in the two languages along these scales emphasizes the restrictions of omissions in Czech and the high degree of freedom in Russian. Moreover, verb omissions in Russian can lead to changes in the meaning of a sentence, whereas they seem to be merely a stylistic device in Czech.

\section{[1] INTRODUCTION}

Among the languages of Europe, Russian holds a special position with regard to its possibilities of omitting certain syntactical constituents. In this paper, the unique possibilities of Russian verb omission will be pointed out through a comparison to the rather restricted possibilities of such omissions in Czech and it will be shown that in Russian omissions are much more than simply "holes" in sentences just as much as the swiss cheese which gave this paper its title is not produced by drilling holes into other cheese sorts.

One of the first linguists to address the question of verb omission in Russian was Širjaev in the collective monograph Русская разговорная речь (Širjaev 1973, 288). He postulates that the omission of verbs is a characteristic feature of colloquial Russian. In comparison with other Slavic and European languages, it turns out that this feature is not only characteristic, but also exceptional. The degree of freedom Russian allows when it comes to empty verb strings was illustrated by Mel'čuk (1995), who demonstrated that it is possible to omit any verb as long as it 
denotes an action ${ }^{1}$ and requires an object (Mel'čuk 1995, 192). This result is insofar surprising as it would seem important that a sentence preserves the root of its dependency tree. In Russian, it is possible to omit verbs in all tenses, as well as of both aspects and even verbs in the conditional mood. The only restriction which seems to hold for all groups of verbs is that a clause with an omitted verb cannot contain a total negation (see Weiss (1993)). In Czech, omissions are allowed in few cases and verb omissions are prevalent in certain contexts (e.g. advice, order) or a style of narration (e.g. dynamic narrative sequence). A common use of omitted verbs in Czech, Russian, and other European languages was for political, commercial and other slogans, since the omission lends them brevity and can add emphasis.

The data analyzed for this paper consists of recorded spontaneous utterances as well as written text representing various genres, especially such genres which try to imitate spoken language (e.g. comic books, films, plays, prose dialogue). Translations of prose, drama, or films whose original language is not Russian or Czech help to demonstrate that verb omissions are a natural formation in Russian and occur in translations of sentences which, in their original language, featured a verb. For obvious reasons, a study based on an electronic corpus is somewhat limited, and in the future, some effort should be devoted to finding a possibility of searching for empty strings.

Although the issue of missing verbs in Russian has been addressed in a number of studies (see, e.g., Mel'čuk (1974, 1995), Weiss (1993), Wiemer (1996), Ščadneva (2000), Saj (2002)) a classification scheme which would fully account for this phenomenon has yet to be developed. In fact, the term for the omission itself is subject to discussion. In this paper, I will use the terminology presented by Apresjan (1986). An ellipsis must be unAmbiguously ReCoverable. Moreover, an ellipsis is an omission which is "compulsory in certain syntactic contexts, i.e. happens automatically" (Apresjan 1986, 112). Therefore, a distinction can be made between mandatory and optional ellipses. On the other hand, a ZERO, according to Apresjan, is "an omission not required by its syntactic context and, therefore, a semantically relevant absence of a linguistic construct" (Apresjan 1986, 113). Every zero has a certain meaning, but it is not possible to reconstruct that meaning, since it DOES NOT MATCH THE MEANING OF ANY EXISTING RUSSIAN LEXEME (Apresjan 1986, 113). A classical example of a zero would be:

$$
\begin{aligned}
& \text { Улицу засыпали } \emptyset_{\text {люди }} \text { песком. } \\
& \text { street-ACC covered-3rd.PL } \emptyset_{\text {people }} \text { sand-INSTR } \\
& \text { 'They covered the street with sand.' (from (Mel'čuk 1995, 180)) }
\end{aligned}
$$

[1] Mel'čuk does not specify what his term action encompasses. However, this distinction is not of importance, since the omission of verbs is not restricted to actions, e.g. в кого это он $\emptyset$ ? 'whom does he take after?' with $\emptyset$ = уродился 'he was born.' 
While it is clear that (1) clearly means that some person or people must have covered the street with sand, the omitted word consists of an abstract complex of semes; it is impossible to complete the sentence with the missing word without changing the meaning.

This is different for (2):

$$
\begin{aligned}
& \text { Вам куда } \emptyset ? \\
& \text { you-DAT where to } \emptyset ? \\
& \text { 'Where do you need to go?' }
\end{aligned}
$$

It is not possible to classify (2) as an ellipsis, since there is not only one single lexeme that would be fit to replace the empty string. What we are dealing with here is rather a whole set of possible lexemes or combinations of lexemes that would do the job (е.g. ехать, надо ехать, идти, ...). On the other hand, it is just as impossible to call this omission a zero, since the completion of the sentence with a concrete lexeme is possible and does not change its meaning. This means that this sort of omission can be assigned an intermediate status between an ellipsis and a zero - while the empty string represents an abstract complex of semes, it is still possible to find matching verbs to complete the sentence. I will call this omission simply VERB OMISSION ${ }^{2}$ for lack of a more appropriate term. There are verb omissions where only one possible solution can be inserted and, hence, they would be classified as ellipses. They represent the edge of the continuum of verb omissions presented here.

\section{[2] PLACING THE OMISSIONS ALONG TWO SCALES}

After establishing that the verb omissions ${ }^{3}$ I am analyzing in this paper are neither ellipses nor zeros, we are left with a highly heterogeneous group of omissions. To bring some order into this group, one can determine two scales along whose continua the different kinds of verb omissions can be placed.

The first spreads between UNAMBIGUOUSLY RECOVERABLE (meaning ellipsis) and AMBIGUOUS/VAGUE, going up to not recoverable, the edge on which zeros can be placed. An example for a low degree of ambiguity/vagueness is (3), where a choice can be made only between two different temporal/aspectual forms of one lexeme (понравился or нравится). (4) shows an omission which can be replaced by numerous lexemes/forms, such as дают, заплатить, платят, надо дать, ...

[2] The postulation of a third category of omissions was disputed by Mel'čuk (1995) who deemed such a category illogical, since he maintains that all omissions must be classifiable as either ellipses or zeros with no grey area in-between. However, many failed attempts at placing most of the verb omissions in one of the two categories suggest the existence of this third category.

[3] From now on, whenever verb omissions are mentioned, this term excludes ellipses and zeros. 
(3) Как тебе Лондон $\emptyset$ ?

how you-DAT London $\emptyset$ ?

'How did you like London?'

(4) Мне нужна новая картина. Сколько ему Øза

I-DAT need new painting-NOM. How much him-DAT $\emptyset$ for

поддельного Сезанна?

fake Cézanne-ACC?

'I need a new painting. How much money does he get paid for a fake Cézanne?'

Most verb omissions are to be found between the two edges of the scale, displaying higher or lower degrees of ambiguity/vagueness.

The second continuum spans between PHRASEOLOGICALLY BOUND CLAUSES and FREE FORMATIONS/CLAUSES. Verb omissions can be found along the entire scale, with clauses like (4) on the free formation end and expressions like (5) and (6) on the phraseologically bound end.

(5) Ты что, совсем уже $\emptyset$ ?

you what completely already $\emptyset$ ?

'Have you gone completely mad?'

(6) Co ty na to $\emptyset$ ?

what you on this $\emptyset$ ?

'What's your opinion on this?'

The differences between omissions within phraseologically bound and free clauses are important for a complete account of verb omissions, their use, the recovering of their meaning by the hearer, and their functioning within a conversation. However, a full analysis of this topic would go far beyond the scope of this paper. The connection between the two scales lies in the fact that phraseologically bound clauses are often prone to having fewer possible complements than free clauses. This is given by the fact that phraseologically bound units are always used in a very specific context. Their meaning is fixed before they are used. The free clauses, on the other hand, standing on their own, can have a wide variety of complements. Their meaning is defined within/through a particular situation and is (usually) not pre-set. If (7) is uttered while somebody is packing a suitcase, the translation would be 'Why are you taking this?' If, however, the person just came home with a bag of groceries, the other person may utter the same sentence with the meaning 'why did you buy this?' This utterance can be used in a wide variety of situations and its meaning is defined through them. Since the context usually determines the lexical item that is missing more or less clearly, the degree of ambiguity is somewhat curbed. Yet, there is still the possibility of 
some ambiguity due to the possibility of temporal, aspectual or modal variation (8a)-(8c).

(7) А это зачем $\emptyset$ ? and this what for $\emptyset$ ?

(8) a. А это зачем берешь/брать/положил?

'what are you taking this for? / why are you taking this?'

b. А это зачем купил?

'why did you buy this?'

c. А это зачем повесил/вешать/тут висит?

'why did you hang this/why should this be hanging here/why is this hanging here?'

[3] SIMILAR USE OF VERB OMISSIONS IN RUSSIAN AND CZECH

To demonstrate that Czech only uses verb omissions in a very restricted way and that they often serve a stylistic/narrative purpose rather than simply being a natural part of everyday speech, similar use of verb omission in Czech and Russian will be presented in this section.

Širjaev (1973) found that in Russian, the most frequently omitted verbs come from three groups: verbs of goal-directed motion (e.g. я на базар, она в школу), verba dicendi (e.g. а он ей: «Подожди!») and verbs denoting violent application of force (е.g. Она ему/его сумкой по голове). However, as stated above, almost any verb can be omitted from a sentence. In Czech, the restrictions are more limiting, but when verbs are omitted, they are mostly from the groups of verbs of motion with a specific goal or verba dicendi (except for a few phraseologically bound expressions, e.g. Jó, pivo, to já $\emptyset$ rád! 'Oh yes, I like beer a lot'). Verbs from these two groups are sometimes found omitted in the following cases.

To create a vivid and possibly entertaining narration of a scene, a verb of fast, goal-directed motion or a verb of violent force can be replaced by an interjection, usually an onomatopoetic representation of the sound that the fast motion or impact of force is imagined to produce, e.g. (9) and (10).

(9) Вот так едешь, а тут тебе баи по голове столбом,... like that drive-2nd.SG, and here you-DAT bang on head-DAT pole-INSTR 'You're driving (normally) and then you suddenly get hit by a pole.' (source: www.forum.rzn.info)

(10) Pes ji skoro dohonil, ale kočka šup a na strom. dog her almost caught-3SG, but cat swoosh and on tree.

'The dog had almost caught it, but the cat quickly climbed up the tree.'

The common feature of Russian and Czech here (i.e. (9) and (10) is that this kind 
of onomatopoetic interjection marks a highly colloquial style, whereas (11) and (12) show sentences typically used in a narrative. Here, the omission serves the purpose of making the narrative depiction of a sequence more dynamic. Russian, again, makes use of this technique (fittingly demonstrated by the fact that one of the most well-known examples for this is from Pushkin's Evgeny Onegin: Татьяна в лес, медведь за нею 'Тat'jana $\emptyset$ into the forest, the bear $\emptyset$ right behind her') more often than Czech does.

(11) Потом $\emptyset$ другой костюм и быстро $\emptyset$ на сцену.

then $\emptyset$ another costume and quickly $\emptyset$ on stage.

'Then he/she/I changed into another costume and quickly returned on the stage.'

$$
\begin{aligned}
& \text { Potom sprcha a rychle } \emptyset \text { do postele, ráno nás } \\
& \text { then shower-NOM and quickly } \emptyset \text { in bed, morning us-ACC } \\
& \text { čeká dlouhá túra. } \\
& \text { awaits.2nd.SG long hike. }
\end{aligned}
$$

'Then we had to shower and go to bed quickly, because the next morning we had a long hiking tour ahead of us.'

(source: www.klaudy.net/pesi-tura-rohace.php)

Example (11) also illustrates that Russian often omits the verb as well as the pronoun at the same time, so that the verb-dropping does not cancel out pro-drop. In fact, (11) would not be a well-formed sentence if the pronoun would be left in the sentence. Where pro-drop is obligatory, the pronoun will be dropped even if the verb is omitted, leaving no indication (but that provided by the context) of the person and number in the sentence. Looking ahead at (13), we can claim that for certain sentences the person and number become irrelevant, since what counts is the remaining information. It does not matter whether we insert second person singular or a modal impersonal form (e.g. с тещей надо/нужно обращатся поосторожней), since the main information is that a man must be cautious about his behavior towards his mother-in-law.

In both Czech and Russian, verbs can be omitted in clauses containing an advice, e.g. (13) and (14), or, even more characteristically, an order, e.g. (15) and (16). In the case of the order, this is especially so if the order is short and easy, often involving a movement of one or several of the addressee's body parts.

C тещей $\emptyset$ по-осторожней.

with mother-in-law $\emptyset$ more carefully.

'You should be careful about your behaviour towards your mother-inlaw.' 
(14) S chřipkou $\emptyset$ rychle do postele. with flu $\emptyset$ quickly in bed.

'If you have the flu, you should get rest.'

(15) Это $\emptyset$ туда!

this $\emptyset$ there!

'Put/throw this over there/up there etc.'

(16) Pravou ruku $\emptyset$ dolů!

right hand $\emptyset$ down.

'Put your right hand down!'

The omission of infinitives is also possible in both languages, although Russian omissions differ from the Czech ones since, again, a greater deal of freedom is displayed. An infinitive in Czech can only be omitted when the clause contains a modal verb, e.g. (17). Since Russian has the modal infinitive, there is no modal verb to remain in the clause, e.g. (17).

(17) Já chci $\emptyset$ do parku.

I want $\emptyset$ to park.

'I want to go to the park.'

(18) Нам куда завтра $\emptyset$ ?

us-DAT where tomorrow $\emptyset$ ?

'Where do we have to go to tomorrow?'

The cases in which Czech permits empty verb strings are similar to those occurring in German and other European languages. In most cases (except the phraseologically bound ones, which differ from language to language), where Czech admits an omission, it is also possible to omit the verb in German and vice versa, whereas most of the omissions which seem natural in spoken Russian are completely ungrammatical when translated into Czech. Phraseologically bound clauses with an omitted verb are also very rare in Czech. So far, I have found only the two presented in this paper (see (6) and pivo, to já rád) and Ruce vzhưru! 'Hands up! (uttered by the police)', which is formed in the same way in both Russian and German (as stated above, short, easy orders, often involving the addressee's own body parts). In regard to the scale of ambiguity/vagueness presented in section [2], Czech occurrences of omitted verbs are always to be found in the lower range of ambiguity/vagueness (if not absolutely on the lower end of the scale, i.e. as an ellipsis). An example like (7) would not be possible in Czech. 
[4] DisRUPTIVE VS. UNPROBLEMATIC AMBIGUITY/VAGUENESS CONNECTED TO VERB OMISSIONS IN RUSSIAN

In contrast to Czech, where ambiguity/vagueness is rare, Russian allows for a greater degree of ambiguity/vagueness. The ambiguity/vagueness can consist in lexical, temporal, aspectual, modal, and pragmatic variation. In the case of lexical and pragmatic ambiguity/vagueness, various degrees (higher or lower) of ambiguity can be observed.

The divergence between the speaker's intent and the hearer's understanding in the following real-life example (19) arises due to temporal ambiguity of the missing verb. After the hearer starts putting the glasses on top of the cupboard, because he assumes that the speaker wants him to do it now, the speaker must specify that the hearer should comply with the request only later after the glasses have dried off. The ambiguity, thus, consists in the difference between, e.g., поставь and поставишь).

A вот эти стаканы $\emptyset$ на верх. [...] Ну не сейчас, пусть сначала And these glasses $\emptyset$ up there. [...] But not now, let first высохнут. dry off-3rd.PL.

'And these glasses go up there. [...] Not yet, let them dry off first.'

In this case, the temporality is of some importance and it is, therefore, necessary for the speaker to be more precise about it. However, in many cases, the temporal information of the missing verb is either clear or not important. For instance, in the already examined example (7) А это зачем $\emptyset$ ?, if the person asking is interested in knowing why the other person is putting something in their luggage, then the distinction between, е.g., кладешь and положил is of no importance whatsoever. The reaction does not depend on the temporal information and thus this information does not have to be specified.

Many cases of lower lexical ambiguity are similar to (20). They represent an abstract verb of goal-specific motion (or, in other examples, any abstract verb encompassing a whole range of different verbs which all share certain semantic features). Usually, it is not necessary for the hearer to know whether the speaker will run, walk or bike to the university and, thus, he will not likely ask for this piece of information. If, however, the hearer knows that there might be the possibility of the speaker taking his car and the hearer wants to ask for a ride, then, for him, the speaker's motion "loses" its abstract quality and he will likely ask for more precision. It is important to treat these two options of understanding the omitted verb, the abstract and the concrete mode of motion, separately.

Я $\emptyset$ в университет.

I $\emptyset$ to university. 
'I'm off to the university.'

In cases of lexical ambiguity of a higher degree, one would expect that more specific information would always be needed. Various verbal and non-verbal factors create the context for a particular utterance and its meaning can become more or less clear at various stages in the conversation, as shown in (22). However, as (21) illustrates, even with a high number of possible inserted verbs, further precision is not always required.

a. A: В вечер кражи, я с книгой лягу в постель.

В: Но вы же ...

A: Вы же?! Кто рвется в музей выкрасть собственную вещь и не хочет объяснить за каким чертом это нужно?! Вы же! [ ...]

A: On the evening of the robbery, I'll lie down with a good book.

B: But you ...

A: But you?! Who wants to break into a museum to steal something she already owns and refuses to tell me why she wants to do this? You!

b. Вы правы, так бы любой $\emptyset$ на вашем месте.

You right, like this conj anyone $\emptyset$ in your place.

'You're right, anyone would react like that.'

(from the Russian translation of the movie How to Steal a Million)

(22) a. А: У него завтра день рождения и я ему Лотрека $\emptyset$.

A: by him tomorrow birthday and I him Lautrec-ACC $\emptyset$.

'It's his birthday tomorrow and I painted/bought/gave him a Lautrec.'

b. В: Ты сама $\emptyset$, что ли? Или купила?

B: you yourself $\emptyset$ what? or bought-2nd.SG.PAST?

'Did you paint it yourself? Or did you buy it?'

c. А: Сама. Как всегда, когда у мена нет денег.

A: (my)self-FEM. like always, when by me not money.

'I painted it myself, as I always do when I'm broke.'

In (21), even though the number of possible "solutions" for the gap is quite high, the main information remains that person B finds A's reasons rational and understandable (whatever her feelings about this rationality might be). The core information remains the same, whether one inserts подумал, отреагировал, поступил, сделал, сказал, ... In (22), on the other hand, the interesting information for person B is whether person A bought a copy or painted one herself. In this case, the core information lies in the unspoken verb and further details are important.

The last kind of ambiguity presented here is modal ambiguity, which, in this 
example, is also linked to pragmatic ambiguity. In (23), the choice between indicative and imperative mood - занесешь 'you will carry' and занеси 'carry' - is insofar important as it determines the degree of politeness the speaker demonstrates towards the hearer. The indicative mood, letting the speaker appear as if he takes the compliance of the other person for granted, is a stronger invasion into the hearer's negative space than the imperative mood.

(23) Цветы $\emptyset$ на верхний этаж.

flowers $\emptyset$ on upper floor.

'Put the flowers upstairs.'

\section{[5] CHANGES IN SENTENCE MEANING DUE TO VERB OMISSION}

Mel'čuk (1995) based his claim that there is no third kind of omission between an ellipsis and a zero lexeme on the fact that the speaker always knows what he would insert in place of the missing verb and that the verb is still present in the meaning-layer of the utterance and only disappears on the surface or text level. While this may be true for some utterances, there seem to be many expressions where speakers themselves, when asked what they would insert, hesitate for a moment or offer multiple solutions, e.g. как тебе Лондон? If somebody for instance says я не нарочно (lit. 'I not on purpose') to express that he is sorry for something, Mel'čuk would expect him to know whether he would insert the general verb сделать 'do' or a verb denoting the specific action, e.g. сбросить 'throw down'. Comparable to (21), the important information (and, thus, probably the one the speaker is most concerned with) is that the speaker is saying that he is sorry. After uttering this sentence, a native speaker was asked which verb she meant and, hence, would insert. She reacted in the expected way, not sure whether she would insert сделала or порвала 'tore apart'.

The next example, however, provides even more solid evidence that Mel'čuk's claim does not hold.

a. Тяжело ... без бабушки.

difficult ... without grandmother.

'It's difficult without a gradmother around.'

b. Мне бы маму сейчас (щас) сюда $\emptyset$, вот бы она с me-DAT CONJ. mama now here $\emptyset$, here CONJ. she with ним возилась!

him play

'I wish my mom was here, she would take care of him.'

(example taken from Weiss (1993), source: Машинный фонд русского языка)

If Mel'čuk's claim was true, then the speaker uttering this would have to be able 
to complete the sentence with the missing verb. However, if she were to do this the result would be something like the following sentence: Мне бы маму сейчас сюда пригласить. 'I wish I could invite my mom here now.' The problem in this sentence consists in the fact that, as soon as a verb that actually fits the sentence structurally is inserted, the sentence changes its meaning. It changes from the initial meaning, which could be paraphrased approximately as follows $Я$ xочy, чтобы мама была здесь сейчас 'I wish my mom was here right now' into the wish to get her mother here. This example shows that there must be more to verb omission than just the simple act of drilling holes into full sentences.

Another example which illustrates the gain in freedom through the omission of a verb is (25). Because of the omission, it is possible to forego the problem which arises if one would try to insert the verb победить 'to defeat' in the respective form into both positions. Since the first empty position requires the verb to take the first person singular, the verb победить would not work, since there is no grammatical form for the first person singular of this verb. In this case, however, the insertion of the verb happens in the mind of the reader and does not necessarily have to take on any proper grammatical form at all. The source of this joke found on a refrigerator magnet is the idiomatic phrase Кто кого? (verbatim 'Who whom?') 'who's the stronger one?' which already contains a verb omission.

$$
\begin{aligned}
& \text { Или я } \emptyset \text { диету, или она } \emptyset \text { меня. } \\
& \text { Or I } \emptyset \text { diet-ACC, or she } \emptyset \text { me-ACC. } \\
& \text { 'Either I defeat the diet or it defeats me.' } \\
& \text { (source: seen on a refrigerator magnet) }
\end{aligned}
$$

\section{[6] SUMMARY}

Whereas Czech is similar to German and other European languages with respect to its restrictions on verb omission, Russian, especially in its colloquial form, can omit a great variety of different verbs. The omissions of verbs can be placed along two scales, which range from phraseologically bound clauses to free clauses and ambiguous/vague to unambiguously recoverable respectively. It is important to examine omissions from different positions on these two scales separately, since they play different roles in conversations and are perceived differently by the hearer. Some ambiguities must be resolved to allow the hearer to have all the information he or she needs, while others function well without being reduced to an unambiguous solution. Those which need to be resolved are utterances where (an important part of) the core information is conveyed by the verb or its temporal or aspectual information.

The omission of verbs should not be treated only as a surface phenomenon, but should also be considered for its potential for changing the meaning of the entire sentence. It is important to be aware of the great diversity of structures 
containing omitted verbs and to not treat all omissions as one homogeneous category.

\section{REFERENCES}

Apresjan, J. D. 1986. Tipy sintaksičeskogo otsutstvija v russkom jazyke. In Problemy semantiki predloženija: vyražennyj i nevyražennyj smysl, 111-114. Krasnojarsk: Krasnojarskij gosudarstvennyj pedagogičeskij institut. Tezisy kraevoj naučnoj konferencii.

Širjaev, E. N. 1973. O nekotorykh pokazatel'nykh nezameščennykh sintaksičeskikh pozicij v vyskazyvanijakh razgovornoj reči. In E.A. Zemskaja (ed.), Russkaja razgovornaja reč, 288-313. Moscow.

Mel'čuk, I. A. 1974. O sintaksičeskom nule. In A. A. Kholodovič (ed.), Tipologija passivnykh konstrukcij. Diatezy i zalogi., 343-361. Leningrad: Nauka.

Mel'čuk, I. A. 1995. Russkij jazyk v modeli «Smysl <-> Text». Moscow: Jazyki russkoj kul'tury.

Saj, S. 2002. Elliptičeskie konstrukcii: struktura i funkcionirovanie (na materiale russkogo jazyka). Unpublished MA thesis.

Ščadneva, V. 2000. Diskursivno obuslovlennye neverbalizovannye komponenty vyskazyvanija. Tartu.

Weiss, D. 1993. Die Faszination der Leere. Die moderne russische Umgangssprache und ihre Liebe zur Null. In Zeitschrift für slavische Philologie LIII. 49-82. Heidelberg.

Wiemer, B. 1996. Klassifikacija nulevykh skazuemykh v russkom jazyke po ikh leksičeskim i referencial'nym kharakteristikam. Studia $z$ filologii polskiej $i$ słowiańskiej 33. 245-273.

AUTHOR CONTACT INFORMATION

Jekaterina Mažara

University of Zürich

Slavic Department

Plattenstr. $43 \mathrm{CH}-8032$ Zürich

Switzerland

jemaz@access.uzh.ch 